Article

\title{
Selectively Assertive: Interventions of India's Supreme Court to Enforce Environmental Laws
}

\author{
Shalini Iyengar ${ }^{1, *}$, Nives Dolšak ${ }^{2}$ and Aseem Prakash ${ }^{3}$ \\ 1 Stanford Law School, 559 Nathan Abbott Way, Stanford, CA 94305, USA \\ 2 School of Marine and Environmental Affairs, University of Washington, Seattle 3707 Brooklyn Avenue NE, \\ Box 355685, University of Washington, Seattle, WA 98195-5685, USA; nives@uw.edu \\ 3 Department of Political Science, UW Center for Environmental Politics, University of Washington, \\ Seattle, WA 98195-5685, USA; aseem@uw.edu \\ * Correspondence: siye@stanford.edu; Tel.: 1-425-681-5097
}

Received: 13 November 2019; Accepted: 13 December 2019; Published: 17 December 2019

check for updates

\begin{abstract}
We examine why India's Supreme Court has selectively intervened to enforce environmental laws. While the Indian Judiciary has substantial political insulation, judges recognize the need for tactical balancing to preserve the legitimacy of their institution. We examine four cases: judicial interventions to check water pollution from tanneries and to phase out diesel engines, and judicial non-intervention to prevent degradation of wetlands and to check crop burning in states adjacent to Delhi. We suggest that judges intervened to correct enforcement failure when they do not anticipate pushback from organized constituencies. Where judicial action imposes costs on a large number of actors and motivates protests from organized groups, the justices have tended to overlook enforcement failures. In sum, in spite of political insulation, judges remain attentive to the popular mood and interest-group politics.
\end{abstract}

Keywords: environmental laws; environmental litigation; pollution; India

\section{Introduction}

The Judiciary is a co-equal branch of the Government, tasked with interpreting the law. While the doctrine of separation of powers assumes that the courts' decisions will be duly obeyed and enforced by the other branches of government, this is sometimes not the case. Scholars note instances of enforcement failures where the Executive fails to enforce judicial decisions either because it does have the resources to do so or because it believes that the political and economic costs of enforcement far outweigh the benefits [1-7].

However, what if such enforcement failures (that is, the Court's judgment is not being enforced by the Executive) are not pushed under the carpet but explicitly brought to the attention of the courts, either suo motu or in response to petitions from concerned citizens or interested parties [8,9]. Faced with this direct and open challenge to their authority, how should the judicial branch respond? While the Judiciary in most countries has some level of political insulation [10] — such as lifetime tenures in US federal courts, or the difficult process of impeaching Supreme Court judges as in India-we expect judges to be carefully attuned to the political, economic, and social implications of their rulings [11]. This is because judges are socially embedded political actors [12] that seek to preserve the legitimacy and therefore, the survivability of their institutions [13].

Consequently, judges have three choices. First, the court does not compel the Executive to correct enforcement failure, either because it feels that efforts will fail, or it does not want confrontation with the Executive. Second, the court takes the Executive to task and demands that the laws and decisions 
be enforced. However, there is a third hybrid route of tactical balancing where the Judiciary demands enforcement but only selectively so [13].

Tactical balancing responds to two competing rationales. Courts probably recognize that institutional authority is preserved only when it is exercised: the "use it or lose it" dictum. However, they also appreciate that overstepping certain social and political bounds can invite political backlash, even when the exercise of the authority might be legally correct. This backlash can undermine both the institution's formal and informal authority. Hence, as strategic actors, we expect courts to selectively assert their authority. Applying Kapiszewki's argument of tactical balancing to the Indian context, we examine how the Indian courts have done so.

Specifically, drawing on environmental law cases from India of judicial assertion and non-assertion, we suggest that judges implicitly work from some sort of cost-benefit calculus from an institutional perspective, especially focusing on the political costs of correcting enforcement failures. We find that in the face of systematic and concerted opposition from entrenched and powerful interest groups, they probably appreciate that the Executive might be powerless to enforce judicial rulings, even if the courts insist that it does so. Recognizing the limitation of state power over societal actors [14], and the need for the state to find accommodation with powerful interest groups, judges may decide to overlook enforcement failure.

Why study India and why environmental cases? We believe that our exploratory study of Indian environmental jurisprudence offers important insights about judicial politics in the context of a developing country and how political and social factors shape what the Judiciary can and cannot do. Decisions made by Indian courts in environmental matters have increasing relevance to both transnational jurisprudence and one-sixth of the world's population and have been cited as advancing the cause of environmental concerns globally. Moreover, studying the Indian Supreme Court's jurisprudence reveals critical insights into judicial decision-making of a court which has been called "the most powerful court in the world" [15] as well as "one of the most accessible high-courts in the world" [16]. However, as we suggest in our paper, this most powerful court recognizes its socially embedded nature and the limits to its authority.

Unlike many other areas of law, environmental cases inherently involve multiple stakeholders with multiple interests. Environmental cases, therefore, reveal how the courts struggle to balance issues of rights, economics, justice, public interest, and ecological concerns. Moreover, although environmental cases often invoke issues of public interest, the "public" is usually not a party before the court; this requires the courts to appoint themselves as guardians of the public weal, a position that departs from the usual conception of objective and neutral judges. Environmental cases are also characterized by the fact that there is often an overlap between violators of the law and those responsible for enforcing it-as some of the cases below indicate, environmental jurisprudence is rich with cases of the Executive either violating or not complying with the law. However, since the courts do not have a separate enforcement arm, the Executive is also responsible for enforcing the courts' orders. This creates an especially interesting conundrum for the court because it involves a real risk that the Executive might simply refuse to enforce judicial rulings and thus invite a direct clash between the two branches of the Government. Thus, our focus on India and environmental cases offer a theoretically rich exploration of Kapiszewki's theory of tactical balancing.

The challenges to the Judiciary might come from several sources. For example, Mark and Zilis [17] note how the Judiciary perceives and evaluates institutional threats from the legislature. Further, drivers of selective enforcement might depend on regime type. For example, in the context of China, Stern [18] examines the notion of political ambivalence to show how Chinese judges sometimes go beyond the legal doctrines and look for political approval from above before deciding on the cases.

Our paper also engages with broader research on enforcement failures. Attempts to correct enforcement failure through judicial intervention and not through political processes such as social movement pressure or through the ballot box are common in contemporary times [19]. In Latin 
American countries such as Colombia and Argentina, the "judicialization of protest" has allowed disadvantaged stakeholders to access the courts [20-22].

But this strategy has a downside, as noted by the critics of rights-based advocacy [23,24]. In the rights-based world, political questions are arbitrated by courts [8,25] — this leads the courts to sometimes take an expansive view of the law, leading to the creation of new judicial doctrines [26,27]. One of the most prominent of these is judicial activism or the perception that the courts go beyond their traditional role of finding and declaring law, towards making law and mandating the manner in which it should be enforced-issues which are seen as being within the competence of the legislature and Executive under the traditional separation of powers doctrine. The issue of limits to judicial power has been the subject of heated debate in India. While some seek to make a distinction between "active" and "activist" judges (with the latter coming in for opprobrium), others have criticized both judicial overreach as well as judicial unresponsiveness [28-32]. We discuss the issue in more detail in a later section on environmental adjudication in India.

Enforcement failures are ubiquitous in India across issue areas. A lack of enforcement sometimes leads India's Judiciary to intervene, often in response to public interest litigations, whereby citizens directly approach the court to compel the Executive to correct the enforcement failures [33]. Since the 1980 's, an increasingly assertive Indian Judiciary has directly intervened to correct enforcement shortfalls but has done so only selectively. Our paper focuses on the potential reasons for the Indian courts' selectiveness in the face of enforcement failures in environmental cases.

We examine four cases of judicial assertion and non-assertion regarding enforcement failures. While we do not test a causal argument, a variation in the dependent variable, judicial assertion, allows us to probe how the independent variables contribute to it [34]. We recognize that scholars working with the comparative methods adopt other approaches to assess the correlation between variables. Thus, the case selection could be informed by approaches which either focus on variations across cases (as in the method of difference, MSSD) or commonalities across cases (as in the method of agreement, MDSD).

Two cases examine the Indian Judiciary's intervention to correct Executive inaction in the context of water pollution in the Kanpur Tanneries case and air pollution in the Delhi Diesel Ban case. In both, while responding to public interest litigation, the courts issued sharply worded orders directing the Executive to enforce existing laws and the courts' decisions, in spite of administrative reluctance to do so. For example, in the diesel ban case, the Judiciary outlined the implementation plan by mandating (inter alia) that Delhi's transportation fleet switch from using diesel compressed natural gas (CNG).

However, in two other cases, the Judiciary has chosen to look the other way although the Executive has manifestly not complied with its orders. The first case concerns the protection of wetlands where the Executive has disregarded multiple judicial directions to demarcate the wetlands. In the second case, the Judiciary has chosen not to use its considerable powers to compel the Executive to stop crop burning in states close to New Delhi-an activity that causes severe air pollution in Delhi each winter. Using these four cases, our exploratory study examines the possible reasons for varying level of judicial assertiveness by drawing on the theory of tactical balancing.

\section{Selective Assertiveness and Enforcement Failures: Theoretical Perspectives}

The issue of selective judicial intervention to correct enforcement failures is not unique to India. A rich literature documents how judges vary in the exercise of judicial assertiveness [35-38] to correct enforcement failure, the influence of public demands on judicial action and the degree to which strong public support affords the Judiciary space to push back against the Executive [12]. In Italy, judges took an active role in fighting against corruption in the Executive and legislative branches [39] while in China, judges have tended to defer to the Executive [40]. In Mexico, the courts appear to be selective in their intervention in politically charged cases [41,42].

Why the selective assertiveness? Scholars recognize the limits of state power in relation to societal actors [14] and why this leads to non-enforcement of rules by the Executive. These issues are salient 
in the literature on failed states [43-45] and areas of limited statehood [46]. There are at least three categories of explanations for enforcement failures. First, enforcement shortfalls reflect endemic corruption [47]. Laws often provide good leverage for regulators to harass those regulated and extract bribes and gratifications. Poorly paid regulators are often willing to look the other way and not crack down on illegal acts. While the above research emerges from the literature on administrative enforcement, it might offer insights to understand for judicial inaction to compel the Executive to enforce the law. For example, could the courts' failures to address enforcement failures reflect corruption within the Judiciary? While there is some evidence to suggest that the Indian Judiciary is not immune to issues of corruption [48], in the absence of robust research, it is hard to make a case that judicial corruption motivates courts to overlook Executive inaction.

Second, even if the Executive is honest, it may not have the capacity to enforce complex laws [49,50]. These capacity deficits can range from their lack of technical expertise to budgetary issues. In numerous cases, Indian courts have cited their deference to the Executive on matters of technical complexity by either setting up committees or granting the Executive more time to enforce a ruling or a law. However, courts have not been consistent in their approach towards such cases. Furthermore, the issue of technical complexity often arises before the courts pass a judgment: we are focused on cases where courts have ruled, the Executive has not enforced the rulings, and the courts have only selectively insisted that the Executive enforce its rulings.

The third explanation, and the focus of this paper, highlights the political incentives facing regulators. While the Executive may enact regulations, often in response to policy crises, its enforcement incentives erode if the regulations are opposed by well-entrenched interest groups [51,52]. As social actors, judges are not oblivious to this political reality when they are called upon to address enforcement failures. As we discuss in this paper, judges might recognize that the state simply does not have the coercive capacity (or is not willing to exercise it) to enforce these laws and that forcing the Executive to act might redirect the public wrath from the Executive to the Judiciary. Thus, instead of forcing an issue and losing face, the judges seek a tactical retreat by not seeking to correct enforcement failure.

Scholars note regulations are susceptible to counter pressures especially if they impose concentrated and visible costs on specific constituencies but create less visible benefits for a large number of people [53]. The opposition to environmental regulations, and more recently to climate policies, falls in this category [54]. At the local level, land use and zoning regulations often provide fertile ground for the backlash against regulators, as is being witnessed in the city of Delhi. The expectation that the Judiciary will be sensitive to such political considerations could result in the court not obliging when some groups ask the courts to compel the Executive to enforce laws. This, in part, is due to the desire to avoid the concerted backlash that might get redirected at them. While judges often have higher levels of political insulation against the popular mood, nevertheless, they probably evaluate the issue not only on its legal merit but on its politics as well given that courts are likely to be aware of the social, economic and political costs of their decisions [12].

Theoretically, our paper draws on Kapiszewski's work on tactical balancing [13]. Kapiszewski suggests that judges take into account six considerations: (1) their own ideology, (2) judicial institutional interests, (3) elected branch preferences, (4) the possible economic or political consequences of their decision, (5) popular opinion regarding the case, and (6) the law and legal considerations. We apply this framework in the Indian context focusing on a subset of factors that are most relevant for the Indian case.

While several aspects of Kapiszewski's framework are directly relevant to the cases we study, not all factors are relevant to the Indian context. For example, judicial ideology is not relevant because the conservative-liberal jurisprudence paradigm is not translatable to the Indian context. India does not have sharply differentiated schools of judicial thoughts/approaches that reflect specific ideological positions. Unlike the US, Indian Supreme Court judges are named by a collegium of peer judges and not nominated by the Executive. There is no Senate (the Upper House) confirmation process. 
Similarly, the preferences of elected branch preferences do not appear to be determinative. This is possibly explained by the courts' relative insulation from the political branch discussed earlier in the article since this has meant that the courts do not necessarily have to be deferential to elected branch preferences. The cases also reveal that while law and legal norms are both relevant and relied upon by the courts, they do not necessarily appear to be determinative for two primary reasons. First, the courts possess considerable discretion in their choice of applicable law as well as in their ability to interpret and even create law and remedies in environmental matters. Secondly, in numerous cases, courts have similar legal and factual bases to come to a different conclusion, thus indicating that the basis of differentiation is rooted in judicial discretion rather than being rooted in law and legal norms.

In addition, we find that the judges in these cases appear to be taking the locus of the enforcement authority into consideration prior to a decision on whether to assert their authority and compel compliance. We thus extend Kapiszewski's framework by suggesting that courts are more likely to assert themselves if they see the enforcement authority as being discrete and having the capacity to enforce the courts' orders. In a federal structure like India's, coordination failures within the different executive levels are endemic and can severely impede the implementation of the courts' orders.

\section{Enforcement of Environmental Laws in India}

As a federal country, India's Constitution divides legislative and administrative competencies between the Centre and the states. This division is demarcated in three separate lists in Schedule VII of the Constitution with the Central Government possessing "residuary" powers of legislation that allows it to legislate on any subject not expressly enumerated in the state (List II) or concurrent lists (List III) (Article 248).

A multiplicity of laws governs the management and prevention of pollution in India. "Pollution" in India is a subject that does not expressly appear in any of the constitutional lists mentioned above although "public health and sanitation" and "water" are both detailed in List II as State subjects-thus indicating that the states would have the sole legislative competency to enact laws on these areas. However, by creatively working the legislative process, the Central Government drafted national legislation on both air and water pollution in the 1970s and 1980s.

In the case of water pollution, the Federal Government used a constitutional provision which allowed it to legislate on a state subject when at least two states requested such a law, a fact that the Water (Prevention and Control of Pollution) Act, 1974 (the Water Act) duly notes. The Water Act also defined water pollution and established a Central Pollution Control Board (CPCB) with subsidiary state pollution control boards (SPCBs) in each state.

In the case of air pollution, the Central Government used a different constitutional provision-one that gives it the legislative competence to pass any law to implement international agreements, even if the subject matter of such a law would otherwise infringe on the division of legislative competencies. The Air (Pollution and Control of Pollution) Act, 1981 (the Air Act) thus states that it was passed in furtherance of India's international commitments under the Stockholm Conference. The Air Act empowers the СРCB established under the Water Act to also prescribe air quality standards in consultation with the state governments and gives the State and central boards the authority to prevent, control, and mitigate air pollution. Ordinarily, the CPCB is under the direct authority of the Central Government and the SPCBs must act as per directions from both the respective state governments as well as the CPCB.

The third critical legislation in the Environment (Protection) Act, 1986, (the EPA) which was passed by the Central Government using a rationale as the Air Act-that is, to implement the decisions taken at the Stockholm Conference in 1972. The EPA is primarily a framework law that gives the Central Government wide-ranging powers to draft rules for protecting the environment and controlling pollution. The EPA also contains enabling provisions for the establishment of statutory committees that can provide technical expertise and specialized advice. Such committees can play a critical role in cases since the courts often rely on them for advice and also for overseeing and monitoring 
the implementation of the courts' orders. For example, in the context of the CNG case, the Central Government established a committee under the EPA, the Environment Pollution (Prevention and Control) Authority, that had representation from all the major stakeholders involved. The Authority's composition and expertise would lead the Supreme Court to rely on it as a fact-finding commission in the case [55].

In spite of having a number of laws, some with fairly stringent provisions, it would not be incorrect to say that they have frequently been honored in the breach. This is in part due to the nature of environmental laws themselves. They are generally non-self-executing and require policies and legislation coupled with the political and administrative will to be fully realized.

While the Supreme Court of India has ruled that the Centre and the states are, in most circumstances, constitutionally co-equals, they have overlapping authorities and competencies in many environmental statutes. Regular and keenly contested elections at both state and federal levels raise the risk of parties being beholden to multiple special interests whose preferences often run counter to some environmental laws. Given that pollution tends to be a multi-source phenomenon that requires coordination across administrative boundaries, it necessitates the cooperation of numerous bodies, each beholden to distinct pressure groups. This suggests that enforcement failures at the administrative level might arise from at least two areas-one, from the diffusion of authorities with often overlapping jurisdictions over various pollution-related matters; and secondly, from the various interest groups that influence policies at different levels. When all bodies are co-equal, it becomes easy to blame the other for inaction and leave it to the courts to force the other parties to comply (as we discuss later in the context of the wetlands and the air pollution cases).

It is in these circumstances that the Judiciary's role becomes especially significant. Research suggests that judicial roles can be critical in issues where the "solutions" involve the imposition of significant political and social costs $[9,56]$. This is particularly true in countries such as India where the Judiciary commands wide deference-the political parties charged with implemented an unpopular court order can avoid taking responsibility for the decision by placing the blame for it squarely at the courts' doorstep.

\section{Environmental Adjudication in India}

India's Judiciary has a unified hierarchical structure that places the Indian Supreme Court at the apex of the judicial system. The Supreme Court enjoys far-reaching powers and its judgments are legally binding on all authorities within the country. The Constitution privileges the Supreme Court and guarantees its independence while giving it far-reaching powers-for example, Article 141 of the Constitution states that the "law declared by Supreme Court shall be binding on all courts in India" and Article 142 of the Constitution states that "the Supreme Court [ ... ] may pass such decree or make such order as is necessary for doing complete justice [ ... ]". There is widespread acceptance that the Supreme Court's decisions have the weight of law and in the absence of a later intervention by the legislature, hold ground as the applicable legal provisions on the subject.

The courts have long been active in environmental matters in India with the most significant jurisprudence emerging from cases dating from the 1980s onwards. Rightly or wrongly, these decisions cemented the courts' "activist" reputation since they, inter alia, introduced the concept of public interest litigations, relaxed the rules of standing (making it easier for affected persons and concerned citizens to approach the courts), and also began articulating important environmental principles to guide policy and decisions in the country $[57,58]$. Thus, the courts' role has slowly transformed from being primarily geared towards settling disputes towards one that actively attempted to manage and prevent the issues at hand, very often through a device known as a "continuing mandamus". This refers to a mechanism used by the courts to monitor Executive implementation and enforcement. It is most frequently used by the Court to pass a series of interim orders and to ask parties to report on compliance with these orders in lieu of passing a final decision (Sahu, 2008). 
Environment and health came to be seen as a related cluster of rights and the courts have acknowledged that a right to clean environment, clean air and clean water is an intrinsic part of a right to health [59]. From 2010 onwards, India has also established the National Green Tribunal (NGT) which is a specialized environmental court established under the National Green Tribunals Act, 2010. The NGT has been given the jurisdiction to hear civil cases arising out of seven specified legislations (including the Air Act, the Water Act, and the EPA) and appeals from the decisions of the NGT are made directly to the Supreme Court. The establishment of the NGT has given a further impetus to "green jurisprudence" in India. For example, in 2016, the NGT declared a state of "environmental emergency" in response to Delhi's air crisis with the tribunal noting that "the states owe a constitutional, statutory and public law obligation to provide to its citizens at least breathable if not absolutely clear air to breathe" [60].

The courts' decisions have, however, have met with some criticism. On the one hand, the Judicial Forum is seen as the last recourse for accessing and enforcing environmental rights and court orders have had far-reaching impacts on improving the state of the environment within the country. Arguably, the role of courts in India has also been to emphasize urgency and the need for immediate action in environmental matters. A lesser appreciated role of the courts has also been to provide political cover for parties who might need to take electorally unpopular steps-rather than take responsibility for the action, the Government of the day has often preferred to take the stance that it is merely carrying out the court's orders even in cases where the courts have only directed the implementation of existing government policy (Narain and Bell, 2006). In this assessment, courts have been instrumental in improving the state of the environment within the country by ordering that the Government implement existing policies, and in some cases, to frame new policies. For example, in the recent spate of cases concerning air pollution in Delhi, it is significant to note that the Supreme Court has tried to ensure that the Government remains the policy-maker. For example, in the case of the Graded Responsibility Action Plan (GRAP) 2017 (which intends to trigger a series of responses in the event of elevated air pollution levels), the plan was initially proposed by the Central Pollution Control Board (CPCB) [61] and then approved by the Supreme Court. This plan vested the Environmental Pollution Control Authority (EPCA), a statutory committee under the EPA, with the power to oversee the GRAP's implementation.

On the other hand, scholars view the Supreme Court as having a "middle class bias" [62], as well as its propensity for "judicial over-reach" [63]. Critics have accused the courts of undermining the principles of separation of powers. For them, courts are not the proper forum to determine matters of polycentric governance [3]. These political and policy issues should be handled by the Executive and legislature because they require a necessary balancing of competing political interests. The very nature of such activities indicates that some people will be left worse off than before and hence, democratically elected institutions are best placed to determine such a policy prioritization.

Examining the cases in which the Judiciary has taken action or has refrained from doing so offers important insights into judicial thinking. In the cases examined below, we argue that judicial intervention might well be conditioned on whether the Judiciary perceives that political backlash to their judgment is manageable-for example, when the judicial actions impose concentrated costs on a few actors or when a larger section of the population actively supports the courts' intervention. To illustrate our argument, we examine four environmental cases in the following sections. The first two cases outline instances where the Judiciary has insisted on correcting enforcement failure and while in the latter two, the Judiciary has actively refrained from doing so. This discussion is summarized in the Table 1 below: 
Table 1. Enforcement: Summary of Case.

\begin{tabular}{|c|c|c|c|c|}
\hline & Kanpur Tanneries & $\begin{array}{l}\text { Delhi Compressed } \\
\text { Natural Gas (CNG) }\end{array}$ & Wetlands Case & Delhi Crop Burning \\
\hline Interest group support & $\begin{array}{l}\text { Active support from } \\
\text { environmental groups for } \\
\text { enforcement; strong and } \\
\text { unified public opinion }\end{array}$ & $\begin{array}{l}\text { Active support from } \\
\text { environmental groups for } \\
\text { enforcement; strong } \\
\text { public opinion }\end{array}$ & $\begin{array}{l}\text { Opposition from organized } \\
\text { constituency asking against } \\
\text { enforcement; not salient in } \\
\text { public conversation }\end{array}$ & $\begin{array}{l}\text { Strong opposition from framer's lobbies. } \\
\text { Public opinion split; publics in polluting } \\
\text { states oppose enforcement while in Delhi } \\
\text { enforcement is demanded }\end{array}$ \\
\hline $\begin{array}{l}\text { Authorities involved in } \\
\text { enforcement }\end{array}$ & Primarily local government & $\begin{array}{l}\text { Government of National } \\
\text { Capital Region of } \\
\text { Delhi state }\end{array}$ & $\begin{array}{l}\text { Central and multiple } \\
\text { State authorities }\end{array}$ & Central and multiple State authorities \\
\hline $\begin{array}{l}\text { Significant economic } \\
\text { repercussions of the decision }\end{array}$ & $\begin{array}{l}\text { Cost concentrated on a } \\
\text { small number of } \\
\text { tannery owner }\end{array}$ & $\begin{array}{l}\text { Costs concentrated on } \\
\text { transport operators }\end{array}$ & $\begin{array}{l}\text { Costs are widespread and } \\
\text { across multiple states }\end{array}$ & $\begin{array}{l}\text { Costs are widespread, across } \\
\text { multiple states }\end{array}$ \\
\hline $\begin{array}{l}\text { Significant political } \\
\text { repercussions of the decision }\end{array}$ & $\begin{array}{l}\text { The constituency worst } \\
\text { affected- the tannery } \\
\text { workers- do not much } \\
\text { political clout }\end{array}$ & $\begin{array}{l}\text { Transport owners do not } \\
\text { have as much political clout } \\
\text { as the vocal middle class }\end{array}$ & $\begin{array}{l}\text { The political benefits of } \\
\text { enforcement are not clear given } \\
\text { the long term and diffused } \\
\text { nature of wetlands health. } \\
\text { However, costs are concentrated }\end{array}$ & $\begin{array}{l}\text { Benefits are significant but limited to } \\
\text { Delhi. The political and economic costs of } \\
\text { enforcement are substantial in the } \\
\text { politically salient areas of Punjab, } \\
\text { Haryana and Western UP, given the } \\
\text { enormous power of the farmer lobby. }\end{array}$ \\
\hline Compliance with courts' orders & Yes, though partial & Yes & No & No \\
\hline $\begin{array}{l}\text { Court makes a credible threat to } \\
\text { use civil and criminal powers to } \\
\text { compel compliance }\end{array}$ & Yes & Yes & No & No \\
\hline
\end{tabular}




\section{Willingness to Correct Enforcement Failures}

\subsection{Water Pollution by Kanpur Tanneries}

The Kanpur tanneries case [64] is often hailed as one of the landmark environmental public interest litigation cases in India. The case was brought on the basis of a petition by MC Mehta [65], a noted environmental campaigner, against the open discharge of toxic industrial effluents into the Ganga. The case involved several rulings but one of the most significant of these was the orders against the tanneries near the city of Kanpur and their continued and long-standing practice of discharging toxic chemicals into the river. The issue of environmental consequences of the leather industry has drawn media attention since, in addition to polluting the environment, the chemicals used in the tanning process cause severe health problems for workers, an issue noted by Human Rights Watch. The documentary, The Toxic Price of Leather, by Sean Gallagher, is a powerful narration of the pollution and public health impact of the tannery industry in Kanpur [66].

In a wide-ranging order, the Supreme Court alluded to both the spiritual significance of the river in the lives of millions of Indians and also to the constitutionally guaranteed right to health and a clean environment to rule that the tanneries must set up effluent treatment plants. The judgment cast a dual responsibility on public and private entities to prevent the dumping of effluents and noted that financial incapacity was no basis to claim an inability to prevent the dumping. In the Court's words:

"Just like an industry which cannot pay minimum wages to its workers cannot be allowed to exist, a tannery, which cannot set up a primary treatment plant, cannot be permitted to continue to be in existence for the adverse effect on the public at large." [64]

Why did the Court assert itself in the Tanneries case? After all, closing them down would have imposed concentrated costs on a specific group of actors. By some estimates, there were 400 tanneries functioning in Kanpur before the intervention of the Court [67].

While this case throws up important questions about the appropriateness of judicial intervention in fundamentally political matters, it is instructive to recall the circumstances that gave rise to this case being heard by the Court. In its order dated 12 January, 1988 the Court pointedly remarked upon the tardiness of the municipal authorities while directing them to take action [68]. This comment would appear to reflect the Court's assessment of institutional interests, legal considerations, and elected branch preferences. As noted above, there are multiple factors that judges consciously and sub-consciously rely upon in their decision making and we argue that institutional interests, preferences of the elected wings of government, the decision's consequences, public opinion, and legal considerations all play a role in their orders and judgments. For example, the Court repeatedly cites the municipal authorities' non-compliance with their statutory responsibilities in justifying their decision to entertain the case as public interest litigation. This justification showed the court couching its intervention as a response to government inaction-an effort which could be seen as a way to pre-empt charges of judicial activism. Moreover, the Court sought to ground their order in existing laws and policies instead of environmental principles in an effort that might reflect their interest in showing that their intervention was based on law rather than perception. Such an approach works to signal that the Judiciary is directing compliance rather than engaging in policy-making.

Arguably, the court believed that local authorities had the capacity to implement its order, and the political costs for doing so would be marginal for the court. This is because most of the groups affected directly by the order did not have the political clout: the majority of the tanners are Muslims, migrant workers, and from the lower castes [69]. Furthermore, there is a very large constituency that favors the cleaning of Ganga since it is widely recognized that Ganga, the holiest of all Indian rivers, is polluted. The causes are many including the dumping of raw sewage and industrial effluents, the disruption of the natural flow due to multiple dams along its course, and the abstraction of an estimated $90-95 \%$ of its flow for irrigation. Indeed, the Ganga Action Plan to clean up the river was launched in the 1980s by the Congress Government and has continued in various incarnations, till this date. 
While the extent of the judgment's effectiveness remains questionable, there was tremendous public and rhetorical support for cleaning of the river Ganga from religious, public health, and ecological points of view. The river is considered holy by many millions of Indians and the health risks posed by the river's pollution were extensively discussed in the decision as well. Thus, while the political costs of disrupting the tannery industry of Kanpur were low, the Court's decision had widespread support. This calculation, we suggest, motivated the Court to take the Government to task for not enforcing the clean water laws and this consideration aligns well with the hypothesis that courts are sensitive to the need to consider public opinion in decisions that impose significant costs on the Government.

\subsection{Air Pollution and the Diesel Ban Case}

While much of the focus over Delhi's air pollution woes has tended to focus on the past few years, it is important to recall that pollution in Delhi is a long-standing issue and, indeed, that the city had appeared to be "winning" its battle against pollutants as recently as a decade ago.

In 1985, alarm at New Delhi's worsening air quality led the noted environmentalist MC Mehta to file a public interest litigation case before the Supreme Court of India. In his petition, Mr. Mehta called attention to the rising levels of air pollution in New Delhi and accused the administration of violating both the right of Delhi's residents to breathe clean air as well as the country's environmental statutes. He called upon the Delhi Government to file an affidavit detailing the steps it had taken to counter air pollution in the capital and, among other things, asked the Court to take up the case against vehicles polluting the city's air [70].

While the first Public Interest Litigation in the matter was filed in 1985, and significant orders in the case were issued from 1991 onwards [55,71], it was not until 1998 that the efforts finally began to bear fruit. The orders from 1991 led to a long line of cases which established statutory committees under the EPA, the appointment of an expert authority, and the drafting of multiple policies, action plans, and white papers before the final Supreme Court order in July 1998 directing, inter alia, a change-over to compressed natural gas (CNG) as the fuel for all commercial vehicles in the capital. In addition to the directions on $\mathrm{CNG}$, the wide-ranging order also saw the Court directing the phase-out of old commercial vehicles, increasing the number of public buses on Delhi's roads and banning certain fuels from being supplied or used within the city. Notably, the Court also threatened contempt proceedings against those failing to adhere to the terms of the order.

Subsequently, in April 1999, the Court laid down emission norms for vehicles registered within New Delhi. After passing these series of orders, the Court's efforts focused on ensuring compliance with its directions within the timelines articulated by it.

The Court's intervention received some level of pushback from organized interests, who were arguably more powerful than the ones in the Kanpur tanneries case. Transport companies and even the Delhi Government noted the technical difficulties, infrastructural deficiencies, commuter welfare, and prohibitive costs were hampering their ability to change over to cleaner fuels and argued that the Court's timelines should be extended. In an interesting contrast to the Court's stance in its later judgments regarding Delhi's air pollution, the Court pushed back against most of such efforts to seek extensions. Indeed, when, in 2001, the Delhi Government even announced its unwillingness to comply with the Court's directions even at the risk of facing contempt proceedings in order to protect the interests of Delhi's residents the Court delivered a sharply worded criticism [72] which ultimately ensured that the Government reversed its rhetoric and filed an affidavit in Court pledging to comply with the Court's directions [73]. Notably, this case shows clearly that the Court was responding to reports in the media and explicitly referenced this in its decision by stating that: "We are distressed at certain reports which have appeared in the print and electronic media, exhibiting defiant attitude on the part of the Delhi Administration to comply with our orders. The attitude, as reflected in the newspapers/electronic media, if correct, is wholly objectionable and not acceptable" [72]. 
Looking at the entire line of orders for over a decade reveals that the Court's final order reflected, in essence, an effort by the Court to prod the administration to fulfill its existing commitments. It is also worthwhile to remember that the court persisted with its insistence for enforcement of the law although such changes did not occur overnight.

We suggest that the Court's willingness to pass orders to correct enforcement failures cohere well with elements of Kapiszewski's theory of tactical balancing. First, the CNG cases posited a relatively discrete technical solution to the problem at hand with little adverse political and economic consequences. This is because while the costs of this change were substantial, they were still reasonably concentrated in a small group of stakeholders: transport operators. While the citizens did face considerable inconvenience, the Court was quick to highlight that this was attributable to Executive inaction rather than its orders. Moreover, given the visibly high levels of air pollution in Delhi, the court's actions had widespread public support [74]. Indeed, once the conversion from diesel to CNG was completed and air pollution came down, all political parties rushed to take credit for it.

The Court is keenly aware of its position vis-à-vis the other wings of Government as well as the manner in which it is perceived by the public at large. One could, thus, argue that the Court's position was at least in part derived from its desire to both enforce the orders that it believed would benefit the public as well as emphasize its standing, a finding that reflects well with the Court's consciousness of its institutional interests as well as its consciousness of the importance of public support.

\section{Failure to Correct Enforcement Shortfalls}

So far, we have discussed cases where the courts have forced the Executive to enforce laws. However, the environmental jurisprudence landscape is also littered with cases where the courts have tacitly allowed the flouting of its orders. Given the courts' extensive powers, such restraint on their part raises an important theoretical issue: why does an actor not exercise its institutional power? The following two cases illustrate examples of how the courts have tolerated blatant non-compliance with both extant laws and the courts' directions.

\subsection{The Wetlands Cases}

Although wetlands cover an estimated $4.7 \%$ of India's surface and perform a variety of critical ecosystem services [75], India's protection for these critical habitats has been surprisingly weak. In spite of extensive Wetlands Protection Rules (Rules) framed under the EPA in 2010, state governments have flouted several of the Rules' mandatory provisions. These provisions include, for example, the requirement that state governments must demarcate and notify the wetlands within their states. This disregard for the protection of wetlands has led to several of these areas being encroached upon (especially for construction), in addition to rampant pollution, leading to the infamous case of "flaming lakes" in Bangalore.

While courts have taken cognizance of the matter and have indicated their awareness of media reporting on the importance of wetlands [76], what is startling is the degree of non-compliance with the courts' directions, particularly at the Supreme Court level. In order after order since at least 2001, the Supreme Court has threatened dire consequences for non-compliance, but little appears to have been accomplished on the ground. For example, just in 2017, the Supreme Court has passed numerous orders asking for the wetlands to be notified, for framing a policy for wetlands conservation [77] and for filing reports on wetlands with the Centre. Even the Court's warnings to the Central Government to not attempt to "hoodwink" the Court [78] and asserting that the latter had "taken [the Court] for a ride" and "[had made] proceedings in the Supreme Court a joke" [78] do not appear to have had a discernible impact on the actual issue of wetlands protection. In spite of threatening authorities with imprisonment for non-compliance, the Court does not appear to have taken any action to enforce orders beyond seemingly hortatory admonitions. Indeed, the Government has frequently responded to the Court's deadlines with requests for more time, which the Court appears to have tacitly granted, in distinction to the approach taken in the cases highlighted above. 
How does one explain the unwillingness of the Court to assert its institutional authority to demand compliance? The answer to the Court's actions may lie with the framework for wetlands management in the country. India has an astonishing diversity of wetlands in different parts of the country and this diversity has made it difficult for the central management of the wetlands-this, in large part, is the reason why the 2010 Rules and the 2017 Rules both envisage a two-tier structure where the competencies are divided between central and state authorities for wetlands management. Even within states, the issue of wetlands is heavily fragmented with the states' environmental ministries and municipal authorities frequently blaming the other for not taking adequate action to protect these areas. At this level of fragmentation, the Supreme Court would need to summon a veritable galaxy of persons if it wanted to hold all the responsible authorities to account for their lapses. Moreover, there is no easy solution available to deal with the wetlands issue-some wetlands are suffering from encroachment while others are suffering from pollution-related impacts (to take just two examples). A policy that demands eviction of encroachers would cause major political upheaval that no political party is willing to face.

Given the granularity of the issue, the federal complications and the number of stakeholders involved (in addition to the governmental authorities, residents, fisherpersons, building developers, construction workers, and grass-cutters are just some of the different groups of affected communities), there are limitations to the courts' ability to effect change on such a widespread and complex issue. Furthermore, apart from a very small community of environmentalists, there is no major pressure group that would support the Court, should it seek this sort of confrontation with a large number of institutional actors. This realization might, thus, offer an explanation as to why the Court has been willing to countenance the Government's failure to enforce both its own laws as well as the courts. Arguably, this is a strategy for institutional preservation because the court probably does not want to be in a situation where the Government defies its order and precipitates a constitutional crisis. This case again reveals the Court's balancing approach—in this case, the issue at hand is non-compliance with both legislation and Court orders, which would, ideally, allow the Court to take strong action and avoid any charges of judicial activism. However, it appears that the Court is mindful of the institutional and political reasons underlying non-compliance as well as of the likelihood that even stern orders, in this case, are likely to be flouted, a scenario that would undermine the Court's authority and standing. While linked to the fact that public support for stringent actions is likely to be diffuse and non-organized, this combination of factors might lead the Court to refrain from taking stern action and, in effect, abstain from enforcing the law.

\subsection{Failure to Ban Crop Burning}

India's failure in dealing with its air pollution woes is particularly problematic-for example, air pollution has been named as being responsible for as many as 1.81 million deaths in 2015 in India [79]. In 2018, the Yale Environmental Performance Index ranked India as 177th among 180 countries globally [80]. Concerns over India's air quality are extensively covered in media and the condition in New Delhi, India's capital city, is often seen as epitomizing India's overall inability to control air pollution. In 2014, the World Health Organisation described Delhi as being the world's most polluted city and in 2017, even Delhi's Chief Minister described the city as a "gas-chamber" [81]. In 2017, the level of air pollutants in Delhi spiked to almost double of the limits that denote "hazardous" levels of pollutants [81], a scenario which has been repeated each year since.

The reasons for Delhi's air pollution woes are neither new nor singular-the problem has persisted since at least the 1980s (although notably, the primary causes of the problem have changed). Compounding the pollution woes is the fact that the protection of the environment and the prevention of air pollution is a fragmented matter in India, an issue similar to the wetlands case. Thus, in spite of the fact that the right to a clean and healthy environment has been affirmed as part of the "right to life" jurisprudence enshrined in Article 21 of the Constitution, pollution has continued to be a persistent problem that successive administrations appear unable to resolve. Given that air pollution 
imposes significant health and environmental costs with especially negative impacts on vulnerable populations, it is striking when the legal, judicial and governmental systems fail to effectively address the matter-air pollution is far from being a niche issue that affects only a few.

Air pollution in Delhi is both point and non-point based, arising from sources within and outside Delhi, is comprised of multiple different pollutants, and shows seasonal variations. The primary culprits are vehicular emissions, coal-based thermal power plants, dust from brick kilns and construction, and biomass burning (which includes both burning of crop residue in the neighboring states and fuel for heat and cooking) [82]. Farmers in neighboring states like Punjab and Haryana contribute significantly to India's food security owing to their production of rice and wheat. They burn crop residue because they seek to harvest rice, a monsoon crop, and prepare that land for wheat, a winter crop, within a very short time period. Crop burning is a quick and almost zero-cost way to remove the stubble left after rice has been harvested-this includes both the crop stubble left on the field but also the rice husk and straw.

We focus on crop burning in neighboring states of Punjab, Haryana and Uttar Pradesh since experts attribute much of winter air pollution to these sources. The success of the Court's intervention in the Delhi CNG case created expectations that Court's will be able to ensure the enforcement of the ban on crop burning. Yet, the court has failed to assert itself in this case. Why so?

There are two significant differences between the CNG cases and the crop burning case that have affected the Court's political calculus. In the CNG case, there was sufficient data and clear evidence that indicated that vehicular pollution in Delhi was responsible for $72 \%$ of its air pollution and, moreover, it was possible to curb it by mandating CNG as a substitute fuel [62]. The Court had to get its ruling enforced within Delhi's territory and this made it an intra-state matter, albeit one requiring the coordination of multiple authorities. The availability of technology and the fact that both the benefits and costs of banning diesel and switching over to CNG would be borne by citizens of Delhi made enforcement issues less politically problematic. Viewed this way, the court would not be portrayed as exhibiting a "Delhi bias" in its rulings.

In contrast, the crop burning issue involves not just multiple authorities, but it also crosses state boundaries. The political implications are obvious: the costs of curbing crop burning are borne by farmers of Punjab, Haryana and Uttar Pradesh while the benefits of clean air are predominantly accruing to citizens of Delhi. Furthermore, the elections to the state governments in these states are highly competitive; it is not surprising that no political party there has come out in favor of a burning ban. All ask for federal subsidies for the farmers to buy machines that would allow them to remove the crop stubble in a short time period so that the land could be prepared for the planting of the next crop [83].

The air pollution cases highlight the limits of granting powers to co-equal bodies and the need for Central Governmental intervention in order to break the deadlock, as it were. It also reveals that legal and political mechanisms are intertwined and that no Court, howsoever powerful it might be, operates in a vacuum. The air pollution cases have witnessed, for instance, that the State Government pleads an inability to convince its counterpart governments to curb crop stubble burning. While it is possible that the Delhi Government could take the errant government to court for its failure to abide by court orders, doing so would have political costs. The Indian federal system has had cases of states suing other each other-for example, in the cases relating to the division of river waters (with the Supreme Court enjoying original jurisdiction in such matters) but there has been no known precedent in environmental cases.

The air pollution cases also reveal substantial limits to the authority of courts in the country. The courts are immensely powerful but they are also reliant on the other wings on government for the enforcement of their orders and this contradiction makes them more open to criticisms of ineffectualness. In the air pollution cases, what makes the issue more difficult is that few state governments admit to a desire to flout the court's orders- they are far more likely to plead for more time and note their inability to enforce the orders. Without technical and cogent evidence to the contrary, the Courts' 
hands are, thus, tied. The Delhi crop burning case shows the Court's consciousness of the reasons for non-compliance and its willingness to come to a conclusion as to the extent to which governments can be ordered to follow a certain course of action. In this case, while there is significant public support within New Delhi, such public support is likely to be missing across the areas where the decision will need to be enforced (and, indeed, it is likely that negative reactions to the Court's orders will be organized).

\section{Conclusions}

The legal system is intertwined with the political system. The failure of the political and administrative system has led citizens and nongovernmental organizations to take recourse to the legal system $[84,85]$. Yet, courts may not be the best venue to resolve all policy problems, especially the ones that entail significant political compromise.

The theory of tactical balancing [13] suggests that courts take into account institutional interest, public opinion, governmental preferences, and legal principles in taking their decisions. Understanding that multiple factors drive the courts' decision making can help explain its "selective assertiveness" [13]. The cases above examine Kapiszewski's framework in the Indian context and highlight how the Supreme Court of India appears to be balancing a combination of its institutional interest, public reactions (with a focus on assessing the reactions and power of organized constituencies), potential political and economic costs, elected branch preferences and an assessment of the power of organized constituencies to guide its choices about correcting enforcement failures.

The Court's consciousness of public sentiment is reflected in the numerous decisions and hearings where the courts have indicated their awareness of media reporting and public sentiment about cases. In addition, the Supreme Court has used its suo motu powers to take cognizance of cases on the basis of letters to the editor (its so-called "epistolary jurisdiction") and newspaper reports. Viewed this way, the Court is a socially embedded actor that recognizes the limits to its institutional authority. Arguably, such limits can change if, for example, there is greater support by organized constituencies for environmental protection. Faced with a new set of political calculus, courts might become assertive to ensure the legal protection for the environment. For example, if, as we argue above, the Court is more inclined to act in cases where there is strong public support, then the strategy for environmental activists would be to engage with creating a critical public constituency for "greener" decision-making which would, consequently, lower the "costs" that the Government and the Court have to consider in their decision-making. Above all, this research contributes to an understanding that the court should not be seen as the ultimate forum for environmental governance in India but rather, it should be seen as one of many spaces where normative values about governance priorities must be debated and where the courts are just one actor, albeit one with vast powers. [86]

This paper does not offer a causal test of the conditions under which judges can be expected to be selectively assertive. This sort of hypothesis needs to be tested on a large dataset. Future research could include testing the selective assertion thesis in a broader set of cases (across issue areas and countries) and parsing the judgments to look for indications of the weight that the judges appear to give to factors such as public opinion and institutional interest. Examining the trends in such decision-making and the degree to which they can be correlated with social, political, economic, and legal factors might also yield a promising avenue for future research.

Finally, our work offers important areas for future research, both for the study of judicial behavior and interest group mobilization to influence that behavior. For example, if judges do decide to become selectively assertive, might it create perverse incentives of interest groups to take to the street and even indulge in violent protests?

Author Contributions: All authors contributed equally to the research and drafting of this paper.

Funding: This research received no external funding.

Conflicts of Interest: The authors declare no conflict of interest. 


\section{References}

1. Bell, R.; Russell, C. Environmental policy for developing countries. Issues Sci. Technol. 2002, 18, 63-70.

2. Dasgupta, S.; Wheeler, D.; Mody, A.; Roy, S. Environmental Regulation and Development: A Cross-Country Empirical Analysis; The World Bank: Washington, DC, USA, 1999.

3. Fisher, E. Environmental Law as 'Hot' Law. J. Environ. Law 2013, 25, 347-358. [CrossRef]

4. Gray, W.; Shimshack, J. The effectiveness of environmental monitoring and enforcement: A review of the empirical evidence. Rev. Environ. Econ. Policy 2011, 5, 3-24. [CrossRef]

5. Konisky, D. Inequities in enforcement? Environmental justice and government performance. J. Policy Anal. Manag. 2009, 28, 102-121. [CrossRef]

6. Spriggs, J. The supreme court and federal administrative agencies: A resource-based theory and analysis of judicial impact. Am. J. Political Sci. 1996, 40, 1122-1151. [CrossRef]

7. Stigler. G. The optimum enforcement of laws. J. Political Econ. 1970, 78, 526-536. [CrossRef]

8. Shapiro, M.; Sweet, A. The New Constitutional Politics of Europe. Comp. Political Stud. 1994, 26, $397-420$. [CrossRef]

9. Tate, N. Courts and Crisis Regimes: A Theory Sketch with Asian Case Studies. Political Res. Q. 1993, 46, 311-338. [CrossRef]

10. Larkins, C. Judicial Independence and Democratiziation: A Theoretical and Conceptual Analysis. Am. J. Comp. Law 1996, 44, 605. [CrossRef]

11. Hanssen, A. Learning about Judicial Independence: Institutional Change in the State Courts. J. Leg. Stud. 2004, 33, 431-473. [CrossRef]

12. Kapiszewski, D.; Taylor, M. Doing courts justice? Studying judicial politics in Latin America. Perspect. Politics 2008, 6, 741-767. [CrossRef]

13. Kapiszewski, D. Tactical balancing: High court decision making on politically crucial cases. Law Soc. Rev. 2011, 45, 471-506. [CrossRef]

14. Migdal, J. Strong Societies and Weak States: State-Society Relations and State Capabilities in the Third World; Princeton University Press: Princeton, NJ, USA, 1988.

15. Fischer, A. Higher Lawmaking as a Political Resource. In Sovereignty and Diversity; Eleven University Press: Oxford, UK, 2008.

16. Robinson, N. Structure Matters: The Impact of Court Structure on the Indian and U.S. Supreme Courts. Am. J. Comp. Law 2013, 61, 173-208. [CrossRef]

17. Mark, A.; Zilis, M.A. Blurring Institutional Boundaries: Judges' Perceptions of Threats to Judicial Independence. J. Law Court. 2018, 6, 333-353. [CrossRef]

18. Stern, R. Environmental Litigation in China: A Study in Political Ambivalence; Cambridge University Press: Cambridge, MA, USA, 2013.

19. Uvin, P. From the right to development to the rights-based approach: How 'human rights' entered development. Dev. Pract. 2007, 17, 597-606. [CrossRef]

20. Behrend, J. Mobilization and accountability: A study of social control in the 'Ca bezas' case in Argentina. In Enforcing the Rule of Law: Social Accountability in the New Latin American Democracies; Peruzzotti, E., Smulovitz, C., Eds.; University of Pittsburgh Press: Pittsburgh, PA, USA, 2006.

21. Espinosa, M.J.C. The Judicialization of Politics in Colombia: The Old and the New. In The Judicialization of Politics in Latin America; Palgrave Macmillan: New York, NY, USA, 2005; pp. 67-103.

22. Smulovitz, C. Judicialization of protest in Argentina: The case of Corralito. In Enforcing the Rule of Law: Social Accountability in the New Latin American Democracies; Peruzzotti, E., Smulovitz, C., Eds.; University of Pittsburgh Press: Pittsburgh, PA, USA, 2006.

23. Cousins, B. Capitalism obscured: The limits of law and rights-based approaches to poverty reduction and development. J. Peasant Stud. 2009, 36, 893-908. [CrossRef]

24. Kashwan, P. The politics of rights-based approaches in conservation. Land Use Policy 2013, 31, 613-626. [CrossRef]

25. Tate, N.; Vallinderb, T. (Eds.) The Global Expansion of Judicial Power; New York University Press: New York, NY, USA, 1997.

26. Canon, B. Defining the dimensions of judicial activism. Judicature 1982, 66, 236. 
27. Kmiec, K. The origin and current meanings of judicial activism. Calif. Law Rev. 2004, 92, 1441-1476. [CrossRef]

28. Dey, B. Judicial Activism as Constitutional Panacea: An Appraisal. Indian J. Public Adm. 1999, 45, 440-451. [CrossRef]

29. Fowkes, J. Civil procedure in public interest litigation: Tradition, collaboration and the managerial judge. Camb. J. Int. Comp. Law 2012, 1, 235-253. [CrossRef]

30. Khosla, M. Addressing judicial activism in the Indian Supreme Court: Towards an evolved debate. Hastings Int. Comp. Law Rev. 2009, 32, 55.

31. Pillay, A. Revisiting the Indian Experience of Economic and Social Rights Adjudication: The Need for a Principled Approach to Judicial Activism and Restraint. Int. Comp. Law Q. 2014, 63, 385-408. [CrossRef]

32. Sathe, S. Judicial Activism in India Transgressing Borders and Enforcing Limits; Oxford University Press: Oxford, UK, 2002.

33. Bhagwati, P. Judicial activism and public interest litigation. Columbia J. Transnatl. Law 1984, 23, 561-578.

34. King, G.; Keohane, R.O.; Verba, S. Designing Social Inquiry: Scientific Inference in Qualitative Research; Princeton University Press: Princeton, NJ, USA, 1994.

35. Hilbink, L. The origins of positive judicial independence. World Politics 2012, 64, 587-621. [CrossRef]

36. Mate, M. Elite Institutionalism and Judicial Assertiveness in the Supreme Court of India. Temple Int. Comp. Law J. 2014, 28, 361.

37. Scalia, A. Judicial deference to administrative interpretations of law. Duke Law J. 1989, 3, 511-521. [CrossRef]

38. Vondoepp, P. Politics and judicial assertiveness in emerging democracies: High Court behavior in Malawi and Zambia. Political Res. Q. 2006, 59, 389-399. [CrossRef]

39. Della Porta, D. A judges' revolution? Political corruption and the judiciary in Italy. Eur. J. Political Res. 2000, 39, 1-21. [CrossRef]

40. Gong, T. Dependent judiciary and unaccountable judges: Judicial corruption in contemporary China. China Review 2004, 4, 33-54.

41. Huneeus, A. The Dynamics of Judicial Transition: Judges, Pinochet-Era Claims, and the Question of Judicial Legitimacy in Chile (1998-2005). Ph.D. Dissertation, Jurisprudence and Social Policy Program, University of California, Berkeley, CA, USA, 2006.

42. Staton, J.K. Judicial Activism and Public Authority Compliance: The Role of Public Support in the Mexican Separation-of-Powers System. Ph.D. Dissertation, Department of Political Science, University of Washington, Seattle, WA, USA, 2002.

43. Brinkerhoff, D. Rebuilding governance in failed states and post-conflict societies: Core concepts and cross-cutting themes. Public Adm. Dev. 2005, 25, 3-14. [CrossRef]

44. Bøås, M.; Jennings, K. 'Failed states' and 'state failure': Threats or opportunities? Globalizations 2007, 4, 475-485. [CrossRef]

45. Gros, J. Towards a taxonomy of failed states in the New World Order: Decaying Somalia, Liberia, Rwanda and Haiti. Third World Q. 1996, 17, 455-472. [CrossRef]

46. Börzel, T.; Risse, T. Dysfunctional state institutions, trust, and governance in areas of limited statehood. Regul. Gov. 2016, 10, 149-160. [CrossRef]

47. Fisman, R.; Miguel, E. Corruption, norms, and legal enforcement: Evidence from diplomatic parking tickets. J. Political Econ. 2007, 115, 1020-1048. [CrossRef]

48. Transparency International. Global Corruption Report 2007: Corruption and Judicial Systems; Transparency International: Berlin, Germany, 2007.

49. May, P.; Wood, R. At the regulatory front lines: Inspectors' enforcement styles and regulatory compliance. J. Public Adm. Res. Theory 2003, 13, 117-139. [CrossRef]

50. Schwartz, J. The impact of state capacity on enforcement of environmental policies: The case of China. J. Environ. Dev. 2003, 12, 50. [CrossRef]

51. Ho, M. Weakened state and social movement: The paradox of Taiwanese environmental politics after the power transfer. J. Contemp. China 2005, 14, 339-352. [CrossRef]

52. Kull, C. Madagascar aflame: Landscape burning as peasant protest, resistance, or a resource management tool? Political Geogr. 2002, 21, 927-953. [CrossRef]

53. Wilson, J. The Politics of Regulation; Basic Books: New York, NY, USA, 1982. 
54. Greenhill, B.; Dolšak, N.; Prakash, A. Exploring the Adaptation-mitigation Relationship: Does Information on the Costs of Adapting to Climate Change Influence Support for Mitigation? Environ. Commun. 2018. [CrossRef]

55. Rosencranz, A.; Jackson, M. The Delhi pollution case: The Supreme Court of India and the limits of judicial power. Columbia J. Environ. Law 2003, 28, 223-244.

56. Sezgin, Y.; Künkler, M. Regulation of "religion" and the "religious": The politics of judicialization and bureaucratization in India and Indonesia. Comp. Stud. Soc. Hist. 2014, 56, 448-478. [CrossRef]

57. Deva, S. Public Interest Litigation in India: A critical review. Civ. Justice Q. 2009, 28, 19-40.

58. Gill, G. The social justice bench of the Supreme Court of India: A new development. Public Law 2016, $392-401$.

59. Bandhua Mukti Morcha v. Union of India AIR 1984 SC 802.

60. Air Pollution: NGT Declares Environmental Emergency in Delhi, Neighboring States. Available online: https://scroll.in/latest/821241/air-pollution-ngt-declares-environmental-emergency-indelhi-neighbouring-states (accessed on 14 December 2019).

61. Air Pollution: EPCA to Enforce Graded Response Plan in Delhi-NCR. Available online: https://imesofindia.indiatimes.com/home/environment/pollution/air-pollution-epca-to-enforce-gradedresponse-plan-in-delhi-ncr/articleshow/56598582.cms (accessed on 14 December 2019).

62. Véron, RRemaking urban environments: The political ecology of air pollution in Delhi. Environ. Plan. 2006, 11, 2093-2109.

63. Sahu, G. Implications of Indian Supreme Court's Innovations for Environmental Jurisprudence. Law Environ. Dev. J. 2008, 1, 3-19.

64. MC Mehta v. Union of India 19874 SCC 463.

65. Mehta, P. The rise of judicial sovereignty. J. Democr. 2007, 18, 70-83. [CrossRef]

66. Hoefe, R. Do Leather Workers Matter? Violating Labour Rights and Environmental Norms in India's Leather Production; Indian Committee of the Netherland: Utrecht, The Netherlands, 2017.

67. Sen, J. The Unmaking of Kanpur's Leather Industry. Available online: https://thewire.in/uncategorised/theunmaking-of-kanpurs-leather-industry. (accessed on 14 December 2019).

68. MC Mehta v. Union of India 1988 AIR 1115.

69. Koshy, J. Nowhere to Hide: How Kanpur's Tanneries are Struggling to Stay Afloat. Available online: https://www.thehindu.com/news/national/other-states/nowhere-to-hide/article24835411.ece (accessed on 14 December 2019).

70. Gill, G. Human rights and the environment in India: Access through public interest litigation. Environ. Law Rev. 2012, 14, 200-218.

71. Agarwal, A.; Narain, S.; Sen, S. The State of India's Environment: Part 1-The Citizen Fifth Report; Centre for Science and Environment: New Delhi, India, 1999.

72. MC Mehta v. Union of India 2001 (3) SCC 763.

73. Roychowdhury, A.; Banerjee, S. The Leapfrog Factor: Clearing the Air in Asian Cities; Centre for Science and Environment: New Delhi, India, 2006.

74. Narain, U.; Bell, R. Who changed Delhi's air? Economic and Political Weekly, 22 April 2006; 1584-1588.

75. Bassi, N.; Kumar, M.; Sharma, A.; Pardha-Saradhi, P. Status of wetlands in India. J. Hydrol. Reg. Stud. 2014, 2, 1-19. [CrossRef]

76. Supreme Court Expresses Concern over the Disappearance of Wetlands in India. Available online: https://economictimes.indiatimes.com/news/politics-and-nation/supreme-court-expresses-concernover-disappearance-of-wetlands-in-india/articleshow/59685015.cms (accessed on 14 December 2019).

77. Supreme Court Directs Centre to Protect over 2 Lakh Wetlands. Available online: https: //timesofindia.indiatimes.com/india/supreme-court-directs-centre-to-preserve-over-2-lakh-wetlands/ articleshow/57049799.cms (accessed on 14 December 2019).

78. Thomas, A. Only 115 Wetlands? Miffed SC Gives Govt. A Week for Fact File. Available online: https://www.dailypioneer.com/todays-newspaper/only-115-wetlands-miffed-sc-gives-govt-a-weekfor-fact-file.html (accessed on 14 December 2019).

79. Prasad, R. Most Pollution Linked Deaths Happen in India. Available online: https://www.thehindu.com/scitech/energy-and-environment/india-ranked-no-1-in-pollution-related-deaths-report/article19887858.ece (accessed on 14 December 2019). 
80. Environmental Performance Index: India. Available online: https://epi.envirocenter.yale.edu/epi-countryreport/IND (accessed on 14 December 2019).

81. Irfan, U. How Delhi Became the most Polluted City on Earth. Available online: https://www.vox.com/energyand-environment/2017/11/22/16666808/india-air-pollution-new-delhi (accessed on 14 December 2019).

82. What's Polluting Delhi's Air? Available online: http://www.urbanemissions.info/blog-pieces/whatspolluting-delhis-air/ (accessed on 14 December 2019).

83. Dolšak, N.; Prakash, A. Saving Delhi from the Toxic Smog: Regulations Have Failed but Financial Incentives Could Work. Available online: https://www.forbes.com/sites/prakashdolsak/2019/11/02/saving-delhi-fromthe-toxic-smog-regulations-have-failed-but-financial-incentives-could-work/\#64ea92261188 (accessed on 14 December 2019).

84. Noorani, A. Citizens' Rights, Judges and State Accountability; Oxford University Press: Oxford, UK, 2002.

85. Pinto, M. Metropolitan City Governance in India; Sage: New Delhi, India, 2000.

86. Iyengar, S.; Dolsak, N.; Prakash, A. Should India's Supreme Court Enforce Regulations? The Regulatory Review, 27 March 2018.

(C) 2019 by the authors. Licensee MDPI, Basel, Switzerland. This article is an open access article distributed under the terms and conditions of the Creative Commons Attribution (CC BY) license (http://creativecommons.org/licenses/by/4.0/). 